\title{
Migration Load, Ecological Opportunity, and Obsessive Compulsive Personality Disorder Etiology: Obsessive Character as an Adaptation to Seasonality
}

\author{
Steven C. Hertler
}

Published online: 22 January 2015

(C) Springer International Publishing 2015

\begin{abstract}
The obsessive-compulsive personality pattern of orderliness, parsimony, and obstinacy was first described and explained by Sigmund Freud. Freud's description was sound, but his explanation was flawed. Further still, no extant etiology, psychoanalytic or otherwise, convincingly accounts for the existence, and intergenerational perpetuation, of obsessive character. Thus, herein is presented a new etiology; an evolutionary etiology that describes obsessive personality, not as a disorder, but as an extreme strategy whose imbalance is a product of post-dispersal evolution. Migration into northerly latitudes brought about a relative release from biotic selective pressures, such as conflict and conspecific competition, and a corresponding increase in abiotic selective pressures, such as cold and seasonal scarcity. Features such as (1) future-oriented thought, (2) parsimoniousness, and (3) compulsive conscientiousness become both viable and intelligible as a temperamental consequence of struggling more exclusively with the elements. After using comparative animal data to demonstrate their biogeographical distribution, the human distribution of these three traits is also shown to be concentrated within northerly latitudes.
\end{abstract}

Keywords Obsessive-compulsive personality · Etiology · Ecology $\cdot$ Evolution $\cdot$ Migration load $\cdot$ Ecological opportunity

\author{
S. C. Hertler $(\square)$ \\ College of New Rochelle, New Rochelle, NY 10801, USA \\ e-mail: stevenhertler@hotmail.com \\ S. C. Hertler \\ e-mail: psychodiagnostics@hotmail.com \\ S. C. Hertler \\ 115 Pine Street, Ridgewood, NJ 07450, USA
}

\section{Introduction: the Obsessive Profile}

Not to be confused with the transient axis I anxiety disorder by the name of obsessive-compulsive disorder, ${ }^{1}$ obsessivecompulsive personality disorder (OCPD) is one of the ten personality disorders recognized by the American Psychiatric Association $(2000,2013)$. Being a personality disorder, OCPD marks the entire adult life and is essentially inseparable from one's person. OCPD is comprised of eight symptoms: (1) preoccupation with details, rules, lists, order, and organization; (2) perfectionism; (3) excessive conscientiousness expressed as constant laboring; (4) excessive conscientiousness expressed as heightened morality; (5) parsimoniousness sometimes manifesting in hoarding; (6) reluctance to collaborate and delegate in work efforts; (7) miserliness and resource conservation in response to potential future

\footnotetext{
${ }^{1}$ Obsessive-compulsive disorder (OCD) and obsessive-compulsive personality disorder (OCPD) are two distinct disorders whose eponymous relationship occasions much confusion. Obsessive personality is as likely to be comorbid with depression or generalized anxiety as with OCD. In turn, many personality disorder studies find OCD comorbidity to be as high in other personality disorders, as in OCPD. As Gibbs and Oltmanns (1995) write: "Although OCD patients are more likely than control subjects to be diagnosed with a personality disorder, they are not more likely to have OCPD than normal controls, nor is OCPD the most frequent type of personality disorder found in these patients." Moreover, OCD is a transient axis I disorder; OCPD is stable axis II disorder. To complete this process of disambiguation, it is only necessary to examine the prevalence rates of both disorders: Many estimates of OCD are below $1 \%$, while the American Psychiatric Association (2013) estimates OCPD to fall between 2.5 and $7.9 \%$, which, as they say, makes OCPD to be "one of the most prevalent personality disorders in the general population," even if everyone with OCPD had OCD traits that would leave $80 \%$ or more of the population of obsessive personalities without OCD traits. However, in reality, liberal estimates show that only $20 \%$ of OCD presentations seem to express broad OCPD personality traits, which amounts to $0.20 \%$ of the general population. The present etiology is concerned with explaining the evolutionary history, not of $0.20 \%$ of a comorbid, impaired clinical population, but of more than $5 \%$ of the general, functional population.
} 
catastrophes; (8) and rigidity and stubbornness (American Psychiatric Association 2013). This obsessive symptom list readily translates into a five-factor personality trait profile.

Obsessive character ${ }^{2}$ is strongly and positively related to the overarching construct of conscientiousness as well as to each of its six facets: competence, order, dutifulness, achievement striving, self-discipline, and deliberation (Lynam and Widiger 2001; Warner et al. 2004; Furnham and Crump 2005). Most recently, in their article entitled Conscientiousness and obsessive compulsive personality disorder, Samuel and Widiger (2011) found obsessive character to be strongly associated with all facets of conscientiousness across five of six trait-based assessments. Other classically defined obsessive features load on other factors. Obsessive character is associated with two facets of neuroticism: First, it is negatively correlated with impulsivity (Lynam and Widiger 2001), as its characteristic over-control would suggest, and second, it is positively correlated with anxiety (Lynam and Widiger 2001), as its membership within the anxious and fearful cluster would suggest. Obsessives are low in openness to experience, with four of six facets showing significant negative correlations with obsessive character. Rigidity, constraint, and social conformity, not surprisingly, cause the obsessive personality to resist the influx of new ideas and to generally remain closed to experience (Warner et al. 2004). In addition, an obsessive character is negatively correlated with the excitement seeking facet of extraversion (Lynam and Widiger 2001). Finally, obsessives are commonly understood to be low in agreeableness (Samuel and Widiger 2010) with volatility (VillemarettePittman et al. 2004), niggardliness (Gay 1989), and reactance (Shapiro 1999) translating into high antagonism (Furnham and Crump 2005), low trust, and low compliance (Widiger and Costa 1994).

Just as Freud was the first to describe obsessive character, so he was the first to explain it (Pfohl and Blum 1991). Having treated it so early and fully with all his authority and acuity, Freud's description and explanation were retained. He told us that obsessive character was a triad of orderliness, parsimony, and stubbornness; he told us that obsessive character was a pattern of parentally instilled dysfunction. Freud's description was sound, but his explanation was flawed (Hertler 2014a). On one hand, Freudian description of obsessive character is like an old house, solidly built in foundation and frame. Time has demanded only maintenance and restoration in the form of elaboration and translation. Whether using the details and language of psychoanalysis or of trait theory, obsessive

\footnotetext{
${ }^{2}$ Obsessive character, or simply obsessive, refers to the personality pattern initially described as anal character by Freud (Gay 1989) and which presently appears as obsessive-compulsive personality disorder in the fifth edition of the American Psychiatric Association's Diagnostic and Statistical Manual of Mental Disorders. The term is meant to be inclusive of all who manifest the personality pattern, whether clinically identified or not.
}

character is manifest; the underlying construct shines through. On the other hand, Freud's explanation is like an old mansion, hastily built and compromised at its core. A want of empirical support (Pollak 1979, 1987) was the first sign of decadence. Yet, it was only in the past decade that the demonstrable heritability of obsessive character (Torgersen et al. 2000) would undermine the foundation of Freudian explanation (Hertler 2014a). Freudian etiologies, whether traditionally psychoanalytic or progressively psychosocial, simply cannot coexist with modern behavioral genetics data (Hertler 2014a). Contrary to psychoanalytic doctrine which attributes causality to parent-child dynamics, behavioral genetics research indicates that the obsessive personality is "particularly strongly influenced by genes" (based on a heritability index of 0.78 ) and not significantly influenced by parental rearing practices (Torgersen et al. 2000; Reichborn-Kjennerud et al. 2007). It seems that obsessives are born, not made. More precisely, while the environment has some causal role in shaping the obsessive personality, this causal role is modest and principally determined by extra-familial factors. Nearly all etiologies of obsessive character are psychoanalytic or psychosocial in nature; consequently, nearly all etiologies are untenable. Even in the vanishingly rare instances in which obsessive biology is considered (Millon and Davis 1996; Hummelen et al. 2008), psychoanalytic language is used and psychoanalytic assumptions are conserved (Hertler 2014b).

\section{The Purpose and Structure of the Present Paper}

Exchanging psychoanalytic assumptions for evolutionary theory, it is herein asserted that obsessive character is a nonconditional, heritable behavioral complex, evolving during the Upper Paleolithic and Early Neolithic in response to changing selective pressures that came of northerly migration out of Africa (Hertler 2014b). Support for this contention, which was only heretofore briefly sketched (Hertler 2014b), will proceed by way of the following sections: First, as part of the process of providing a general adaptationist model and evolutionary history of obsessive origins, the abundance of the tropics (Between the Tropic of Cancer and the Tropic of Capricorn Section) is contrasted with its excess of densitydependent pressures (Exchanging Density-Dependent Stressors for Density-Independent Stressors Section). Subsequently, obsessive character is described as arising as an evolved response to waning density-dependent pressures, chiefly conspecific competition, and waxing densityindependent pressures, chiefly climatic harshness (Human Migration: out of Africa and into the Temperate North Section). Third, to support this model with specifics, three prominent features of obsessive character, future-oriented thought (Time Urgency and Future-Oriented Thought Section), parsimoniousness (Conservation: Collecting, Rationing, and 
Hoarding Section), and compulsive conscientiousness (Compulsive Conscientiousness Section), will be described as ecologically driven adaptations to northern latitudes and costly excesses in tropical latitudes (Obsessive Character in Ecological Context Section). With the evolutionary history and rationale addressed, the paper will move on to discuss the present evolutionary model as it compares with the prevailing psychoanalytic model, especially in relation to heritability, parsimony, falsifiability, and explanatory power (Discussion Section); thereafter, the continuing role of environmental influence is discussed and an experimental model is proposed (A Framework for Empirical Proof Section). Lastly, the discussion section considers extant evidence of biogeographical variance in time urgency and future-oriented thought (Latitudinal Variation in Time Urgency and Future-Oriented Thought Section), parsimony (Latitudinal Variation in Parsimony and Conservation Section), and conscientiousness (Latitudinal Variation in Conscientiousness Section).

\section{Between the Tropic of Cancer and the Tropic of Capricorn}

The geographic distribution of most "terrestrial macroscopic organisms" follows the latitudinal diversity gradient (Sherrat and Wilkinson 2009, page 123; Schluter 2014; Phillimore 2014), which induced Forester to write "...the animal world, from being beautiful, rich, enchanting, between the tropics; falls into... poverty [at higher latitudes]" (Harcourt 2012, page 128). Equatorial regions extending from the Tropic of Cancer to the Tropic of Capricorn with sufficient rainfall afford optimal conditions, beyond which lie the zone of physiological stress and, thereafter, the zone of physiological intolerance (Cox and Moore 2010). The tropics most conspicuously teem with life (MacArthur 1972): Tropical forests often have complex four-layered canopies (Cox and Moore 2010) where high-quality foods are found in relative abundance, supporting a great variety of organisms via "edible plant parts, including nut-like oil seeds, fruit pulp, flowers, leaves, shoots, stems, pith, exudates, and rootstocks..." (Brockman 2005, page 557). In contrast, temperate latitudes support less complex forests, directly and indirectly equating to less biomass (Cox and Moore 2010).

As with other large terrestrial mammals, primate biogeography is highly constrained by the latitudinal diversity gradient. Among nonhuman primates, there are a "few hardy species extending to temperate areas..." (Fleagle 2013, page 170) that survive by varying their diets, broadening their range of habitat use, and evolving larger bodies (Harcourt 2012). Still, high-latitude winters tax primates' ability to survive, decreasing their numbers, lowering diversity, and compelling populations to subsist on low-quality foods during the winter dearth (Harcourt 2012). Thus, nonhuman primates are largely restricted to a narrow latitudinal band, existing primarily in the tropical forests around the equator (Brockman 2005; Lehman and Fleagle 2006). For much of their evolutionary history, human primates showed the same tropical distribution (Stearns and Hoekstra 2005) being confined to the equatorial old world (Sherrat and Wilkinson 2009) sheltered from the "thermoregulatory stress caused by exposure to extreme winter seasons" (Foley 1993, page 31). Not surprisingly, “...the densest populations of humans are still found where climate is most clement and year-round high agricultural production is possible" (Harcourt 2012, page 152).

\section{Exchanging Density-Dependent Stressors}

for Density-Independent Stressors

However, the tropics are not so Edenic. Because the tropics are so conducive to life, they support life in abundance. Abundance creates competition. Competition precipitates character displacement that drives variation and speciation (Pfennig and Pfennig 2012). So, the very diversity of the tropics belies the competition it engenders. High insolation and low thermal stress endow the tropics with more energy at the base of the food chain (Feldhamer et al. 2007), a high carrying capacity, and more life per unit area (Phillimore 2014), with the result being that even space and light become the focus of intense competition. There is then a trade-off: Within the tropics, conspecific competition, parasitism, disease, and other density-dependent biotic stressors serve as the primary checks on survival (Bush et al. 2001; Strulik 2008; Sherrat and Wilkinson 2009; Schmid-Hempel 2011), but as one moves from tropical to temperate latitudes, seasonal variation, cold, scarcity, and other density-independent abiotic stressors predominate (Feldhamer et al. 2007; Phillimore 2014). This relative transition from one form of hardship to another, which is critical to the development of obsessive character, is best captured by Darwin (1859/2005, page 9):

...the number of species of all kinds, and therefore of competitors, decreases northwards; hence in going northward, or in ascending a mountain, we far oftener meet with stunted forms, due to the directly injurious action of climate, than we do in proceeding southwards or in descending a mountain. When we reach the Arctic regions, or snow-capped summits, or absolute deserts, the struggle for life is almost exclusively with the elements.

Human Migration: out of Africa and into the Temperate North

Between 40,000 to 60,000 years ago, humans migrated out of Africa and into the temperate northern lands beyond (Stearns and Hoekstra 2005), thus escaping the increasingly intense conspecific competition of the tropics (Mellars 2006; Shea 
2007). To a very small though measureable extent, humans followed the trend of other organisms exposed to cold, evolving morphological adaptations to subsist in more northerly climates, for example larger and squatter bodies, as per the Bergmann effect, and lower limb-to-body ratio, as per the Allen effect (Harcourt 2012; Gaston 2009; Shryock and Smail 2011). Nevertheless, unlike the robust Neanderthal, humans advanced rapidly into colder climates taking with them their gracile frames (Shryock and Smail 2011). No, it was not major morphological change that enabled dispersal; it was human intelligence, and the technological innovations that derived of it. Fire, clothing, and shelter construction (Harcourt 2012) allowed "...modern humans to colonize northerly latitudes permanently without major anatomical adaptations and during a period of maximum glaciations" (Foley 1993, page 33). As the brain enabled dispersal, so it would be the chief target of post-dispersal evolution (Shryock and Smail 2011; Cochran and Harpending 2009).

Obsessive character is a product of post-dispersal evolution. It is a cognitive/temperamental/behavioral product of struggling more exclusively with the elements. ${ }^{3}$ The obsessive trait complex evolved as hundreds of generations ${ }^{4}$ suffered from migration load, the evolutionary pressure imposed by novel environmental features to which the organism is maladapted (Perin 2009). However, as intimated, migration did not just bring new selective pressures, it mitigated old ones: Migrants left behind the ubiquity of tropical parasites (BarYosef and Belfer-Cohen 2000, 2001; Phillips et al. 2010;

\footnotetext{
3atitude is used as a "crude index of climate" (Harcourt 2012, page 99). While there are complicating ecological conditions, such as soil quality, and local variations, such as altitude (Hemingway and Bynum 2005), latitude incorporates a "host of potential influences, including history, and therefore can encapsulate as an explanation the totality of potential climatic influences" (Harcourt 2012, page 129). Consequently, latitude is presently employed as a valuable proxy for climatic harshness. Nevertheless, it is very likely that the relationship between latitude and obsessive character is curvilinear rather than linear. Traits such as time urgency, parsimony, and hoarding reflect an environment with seasonal vacillations in which times of plenty can be used to prepare for times of scarcity. Also, obsessive conscientiousness needs a target. If, as in arctic environments, there is ever-present cold with no cycles of growth, obsessive labors cannot be deployed in gathering seasonal surplus, constructing wood housing, amassing combustibles, and the like. For these same reasons, one would not expect obsessives to evolve in locally stressed equatorial environments, such as deserts. Though deserts do impose significant climatic stress, and thereby malnourishment and other dangers (Ferro-Luzzi and Branca 1993), these cannot be mitigated by conscientiousness or any other obsessive traits. Only with "modern irrigation agriculture" can nutrition stress in such environments be forestalled (Simondon et al. 1993; Ulijaszek and Strickland 1993)

${ }^{4}$ With generation length operationally defined as 25 years (CavalliSforza et al. 1994), there would be approximately 2000 post-migration generations across which selective pressures could have acted. Wilson (2004), working from this same estimate, believes, as do Cochran and Harpending (2009), that this is more than sufficient time for substantial behavioral changes to take place. The evolution towards an obsessive temperament would have begun upon migration and continued through the Neolithic Revolution.
}

Harcourt 2012) as well as the density (Cavalli-Sforza et al. 1994; Mellars 2006; Reich and Goldstein 1998) and conflict (Shea 2007) that were among the factors precipitating dispersal out of upper Paleolithic Africa (Cavalli-Sforza et al. 1994; Gat 2008). Thus, it is helpful to think not only of migration load but also of ecological opportunity. While both terms concern post-dispersal evolutionary change, each emphasizes a different aspect of it. Again, migration load best captures the strain under which the organism is placed as it suffers from novel ecological conditions to which it is not adapted (Perin 2009), whereas ecological opportunity best captures the range of evolutionary possibilities that accrue to the organism after a sudden release from the evolutionary pressures to which it was adapted (Schluter 2000; Yoder et al. 2010).

Jointly, migration load and ecological opportunity represent the trade-off that redounds to the dispersing human. Northward-dispersing humans assumed a predictable, environmentally imposed hardship while being partially relieved of random, biotically imposed mortality. In this light, an obsessive character, in aggregate, becomes a logically consistent entity and an evolutionarily viable phenotype. On one side, traits such as conscientiousness and future-oriented thought, time urgency, hoarding, and conserving, previously valuable only in moderation, are positively selected to become extreme via climatic extremes. On the other side, the disadvantages of positively selected extremes, such as the risk of losing a hoarded resource to an aggressive competitor, or the subordination of the present and its immediate opportunities that come of future-oriented thought, are less strongly selected against. ${ }^{5}$ As the subsequent sections will describe, futureoriented thought, parsimoniousness, and compulsive conscientiousness mark the obsessive's ecologically mediated evolution.

\footnotetext{
${ }^{5}$ Notwithstanding, it is not that the whole migrating population responded to these selective pressures by developing obsessive character structures. Character diversity, regulated by frequency-dependent evolution, was probably already present prior to migration, and many already extant traits and types continued to hold adaptive value after migration. So, it was still possible to survive by aggression, theft, sharing, and the like. Nevertheless, pre-dispersal strategies derived through adaptive diversification, especially psychopathy and dominance, probably became less tenable, as they are density dependent, with psychopathy requiring a pool of honest population members to parasitize (Mealey 1995) and dominance requiring the concentration of resources to monopolize (Wilson 2000). The same ecological factors that selected for obsessive character would have blunted the adaptive edge of dominant and antisocial types. So, northern migration furthered the process of adaptive diversification among behavioral types and traits and thus allowed obsessive character to develop and become competitive with extant strategies, which, despite ecological conditions, could not supplant. Conspecific parasitism, dominance, alliance formation, and interdependence continued to hold an adaptive value. Thus, an obsessive character became regulated by frequency-dependent forces, holding as a minority character type.
} 


\section{Time Urgency and Future-Oriented Thought}

For an obsessive character, time is used in a "niggardly, thrifty, and cautious manner" (Pollak 1979) and often treated as if it was an "enemy to be fought and overcome..." (Salzman 1985, page 81 ). Living as if there were a stopwatch rapidly ticking away (Shapiro 1999), the "obsessional is painfully aware of the future as an extension of the present" (Salzman 1985, page 81). This "high future time perspective" (Pollak 1987) demotes the present experience to the periphery (Salzman 1985), such that the present becomes the instrument of the future (Eskedal and Demitri 2006). In interpreting traits in their proper ecological context (Nettle 2006; Figueredo et al. 2011), obsessive time urgency becomes comprehensible as an adaptation.

Time, like food, is a resource, reflected in the study of timeenergy budgets (Smith and Winterhalder 1992; Wilson 2000). Anthropogenic impoverishment or enrichment of natural environments has been demonstrated to aggravate or ease time stress among primates (Menon and Poirier 1996; Saj et al. 1999; Li and Rogers 2004; Van Doorn et al. 2010; Ménard et al. 2013). Observation suggests that within tropical environments, unfavorable local conditions can make time budgeting more strict and spare; for example, aridity induces time stress among baboons (Dunbar 1992), while orangutans living in peat swamps experience more time stress relative to those living in masting dipterocarp forests (Morrogh-Bernard et al. 2009). In turn, compared to equatorial environments which are more consistently generous (Wilson 2000), populations inhabiting temperate latitudes are more reliably "faced with time-constrained seasonal stress" (Foley 1993, page 33) that is both "urgent" and "predictable" (Panter-Brick 1993, page 220). Rare among primates, certain baboon populations with ranges extending into more northerly latitudes "experience a scheduling crunch when it comes to allocating time spent in certain maintenance activities (e.g., resting, foraging)" (Brockman 2005, page 552). High latitudes also impact the time budgets of human primates. As Foley (1993, page 32) describes, with seasonal imposition of limited daylight, cold temperatures, and intermittently available resources, "colonization of high latitudes by an essentially seasonal tropical species introduces a new set of time budgeting problems." While selective pressures act to increase foraging time among nonhuman primates living near temperate regions, these same selective pressures have a wider range of possible targets among humans. Humans can budget time more effectively, using it not only to increase foraging during periods of scarcity but also to store and preserve food, cultivate, process skins, make weapons, stash foodstuffs, collect combustibles, cook, construct shelters, and so forth. Given the potentially greater range of adaptive activities that can be pursued by humans, high latitudes should have imposed ever greater pressures to budget time. Accordingly, the future-oriented time urgency of the obsessive might not be a neurotic symptom, but an ecologically derived adaptation to an environment with decreased stochastic mortality and increased foreseeable stressors.

\section{Conservation: Collecting, Rationing, and Hoarding}

The obsessive personality exhibits parsimoniousness, one of three broad traits observed by Freud (Gay 1989) and echoed by Fromm (Millon and Davis 1996). Presently, parsimony is reflected in DSM-V criterion 5 (is unable to discard worn-out or worthless objects even when they have no sentimental value) and criterion 7 (adopts a miserly spending style towards both self and others; money is viewed as something to be hoarded for future catastrophes) (American Psychiatric Association 2000, 2013). Though so rigidly specified (Hertler 2013) as to become diagnostically inefficient (Mataix-Cols et al. 2010; Fossati et al. 2006; Seedat and Stein 2002), criteria 5 and 7 are representative of parsimoniousness, the broad temperamental disposition that induces a range of specific behavioral expressions, all of which center on conserving, collecting, and husbanding resources (Hertler 2013).

Squirrels, because they inhabit so many continents and contain certain species with broad ranges, serve as particularly good animal models from which to draw lessons about the adaptive value of parsimoniousness. For those observing the eastern gray squirrel, "a conspicuous behavior is the annual scatter-hoarding of hard low-perishability nuts and acorns each fall to serve as the winter food store" (Thorington et al. 2012, page 47). Thorington et al. (2012, page 75) report similar hoarding behavior for the Eurasian red squirrel that inhabits locales from "the shores of England to the Bering Strait of Siberia" and the red squirrel ranging from Alaska down to Canada and mountain states of America. Nevertheless, squirrel species occupying more southerly latitudes rarely hoard: For example, Arizona gray squirrels, found across southern Arizona and northern Mexico, eat acorns and walnuts when available, but "rarely cache seeds by scatterhoarding in leaf litter and topsoil (Thorington et al. 2012, page 44)." Similarly, the black giant squirrel found across India, Myanmar, Thailand, Laos, Cambodia, and comparable Southeast Asian regions does not store food. Moreover, Thorington et al. do not report hoarding and caching among the great majority of tropical and subtropical squirrels. Equatorial exceptions, when they occur, hoard less intensively, rely proportionally less on hoarding, store food over shorter periods, or otherwise, occupy low-latitude but high-altitude areas.

While squirrels are a particularly instructive example, a broad survey of animals definitively illustrates hoarding and caching to be an adaptation to food scarcity, which is associated with "north-temperate and arctic regions" where there are "marked seasonal cycles in food availability" (Vander Wall 1990, page 15). Thus, through food hoarding, animals can survive winters when foraging exposes them to extreme cold 
and yields little nutrition. Hoarding is particularly pronounced in certain northerly bird species. Crested tits and willow tits, for instance, rely on stored food, which is the only way they can "exist in northern latitudes in winter." Jays and nutcrackers similarly use periods of abundance to prepare for periods of scarcity. Further strengthening the relationship between hoarding and latitude are patterns of intraspecific diversity and diversity across closely related taxa. For instance, jay and woodpecker populations store little in the tropics, as compared to their northerly counterparts. Similarly, populations of beavers, and other rodents such as deer mice and flying squirrels that have large ranges, progressively store more food with increasing latitude (Vander Wall 1990).

Hundreds of field studies suggest that nonhuman primates almost never store food. Prior to migration, the same was likely true in Homo sapiens, as "in the south, where winters are mild and food more continuously available, stored food is apparently less important in the energetic budget" (Vander Wall 1990, page 249). Also, food storing in equatorial regions is impractical because heat and moisture bring more rapid decomposition, but also because, with greater densities of competitors, it is unlikely that the hoarder will be the one to eventually use the hoarded resource. ${ }^{6}$ So, there is at once less need and more risk associated with hoarding. However, with human migration came a different set of selective pressures pulling for behaviors not fully unlike the hoarding observed in the aforementioned animal species. With large brains and with few morphological adaptations, seasonality might have selected for a broader disposition to conserve through saving, caching, gathering, and rationing that were temperamentally induced but flexibly allocated. This would not have been unlike parsimoniousness as manifested within an obsessive character, which is perhaps better understood as an adaptation than as a symptom.

\section{Compulsive Conscientiousness}

Conscientiousness, diagnostically represented by DSM-V criterion 3 (is excessively devoted to work and productivity),

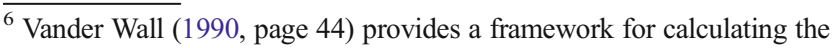
adaptive value of hoarding that puts the following conditions into a costbenefit analysis: (1)"fitness gain from eating one stored item during a future shortage period," (2) "fitness cost of hoarding one item," (3) "probability that the hoarder recovers any one of the items it has hoarded," and (4) "probability that an item not hoarded remains available until the shortage season and is then found by the forager." As Vander Wall explains, "if animals do not recover a sufficiently high proportion of the food they store, the fitness costs of hoarding may outweigh the fitness gains..."

${ }^{7}$ Conscientiousness simultaneously implies laboriousness and scrupulosity. Obsessive character, being extreme across all facets of this trait (Lynam and Widiger 2001; Furnham and Crump 2005; Samuel and Widiger 2011), manifests both poles of conscientiousness. While both poles of conscientiousness are comprehensible as part of the obsessive strategy, only the first one, laboriousness, is treated in the present work.
}

was present from Freud's initial description (Freud 1908/ 1959; Gay 1989) and is increasingly emphasized by contemporary trait investigations (Samuel and Widiger 2010; Widiger et al. 2002; Morey et al. 2003; Deary et al. 1998). ${ }^{7}$ "The most conspicuous fact about the activity of the obsessive compulsive," as Shapiro (1999, page 31) asserts, "is its sheer quantity and, along with this, its intensity and concentration." Importantly, this feeling of being “....pressed by some necessity or requirement..." (Shapiro 1999, page 33) is felt reflexively without any intervening autonomous choice. In the absence of inspiration or immediate external pressure, obsessives live under a "continuous experience of tense deliberateness, a sense of effort, and of trying" (Shapiro 1999, page 31).

Unlike traits such as neuroticism and extraversion, conscientiousness does not readily map onto animal temperament. Only the closely related chimpanzee is described in terms of conscientiousness, and then merely to observe its relative absence across the species, rather than its differential presence within it (Gosling and Mehta 2013). The business of the insect and rodent working assiduously to provision a hive or larder (Gosling and Mehta 2013; Vander Wall 1990) parallels conscientious activity, but only narrowly. Having large brains with powerful frontal lobe function, in combination with opposable thumbs and true bipedal locomotion, human conscientiousness is not associated with a particular end and is not confined to a particular process. Though both can answer adaptive ends, human conscientiousness is then more flexible than animal instinct. At the same time, conscientiousness, as a broad temperamental feature, is quite heritable (Bergeman et al. 1993; Luciano et al. 2006). These are the necessary prerequisites for the amplification of conscientiousness subsequent to dispersal. Because conscientiousness is at once flexible and temperamental, it serves as an obvious evolutionary target following dispersal into "in higher-latitude environments," where "tasks such as producing clothing and shelter eventually became as important as foraging" (Shryock and Smail 2011, page 90). Not surprisingly, Cochran and Harpending (2009, page 117) envision dispersal into northerly latitudes to select for "hardworking" and "self-denying" traits as well as the ability to subordinate present desires to future needs. These suppositions are congruent with descriptions of obsessive character, and conscientiousness, which include factors such as industriousness and responsibility (Roberts et al. 2005) and facets such as dutifulness, achievement striving, and self-discipline (Lynam and Widiger 2001). Notwithstanding that an obsessive character is considered as a disorder of excessive conscientiousness (Widiger et al. 2002; Samuel and Widiger 2009), such extremes might be reflective of evolutionary history rather than being symptomatic of pathological behavior. Put in proper ecological context, conscientiousness became an extreme and compulsive 
temperamental feature ${ }^{8}$ because it reliably preempted the want and exposure peculiar to northerly environments.

\section{Obsessive Character in Ecological Context}

Dispersal, bringing both costs and benefits, represents a tradeoff. Northern migration at once imposed migration load as density-independent abiotic stressors waxed and ecological opportunity as density-dependent biotic stressors waned. From hence come the origins and rationale of obsessive character. With this shift in selective pressures, what was a dominated strategy in the south became a competitive strategy in the north. In equatorial environments, obsessive traits, especially in aggregate, would have been expensive superfluities, reducing fitness via (1) a maladaptive neglect of the present and its opportunities due to reflexively future-oriented cognition; (2) an unnecessary and unwarrantable tendency to conserve resources that would have been better used immediately to satisfy present nutritional demands, or shared with others to increase social standing and strengthen social bonds; and (3) a calorically and relationally costly excess of conscientiousness that would have no necessary end. Thus, when it is taken out of its ecological context and placed within climatically generous environments (Wilson 2000), or certain modern environments that have the luxury to emphasize ideals of balance, harmony, and happiness, obsessive personality is easy to mistake for a pathological pattern. Evaluating the obsessive behavioral phenotype in an ecological vacuum would be the equivalent of taking the bristlecone pine off the windswept heights or the saguaro cactus out of the desiccated desert and mistaking their ecologically evolved extremities for liabilities.

\section{Discussion}

The importance of environmental influence, even the withinfamilies developmental dynamics described as causal in psychoanalytic theory, is not presently discounted. However, as they apply to the core obsessive pattern, within-families developmental dynamics are, in a sense, demoted. Such environmental contributions are in no way necessary or sufficient for the expression of obsessive character. However, they can

\footnotetext{
$\overline{{ }^{8} \text { Shapiro (1999) }}$ and Millon and Davis (1996), among others, are quite clear in describing the reflexive or compulsive quality of obsessive conscientiousness. The labors of the obsessive come from within more than from without; they are temperamentally induced, not consciously chosen. This corresponds to a maxim in sociobiology that states that the instinctiveness and survival value of a trait are positively correlated (Wilson 2004). In other words, when a behavior becomes sufficiently important to the survival of the organism, it is likely that natural selection will select for it to become temperamentally, emotionally, or reflexively induced. With northerly migration, for obsessives, these conditions were met.
}

be considered modestly contributory, in that they may to some degree "influence the form in which the pathology is expressed and play relatively limited roles as primary determinants" (Blaney and Millon 2009). For instance, exacting disciplinary practices and willful struggles for autonomy might have the potential to subtly enhance the magnitude of obsessive traits. Through the processes of identification and dis-identification, parental example might influence whether one accepts and magnifies, or rejects and suppresses, their obsessive traits. Also, the functionality of the obsessive pattern will hinge upon attachment quality and the degree of parental acceptance. An insecure attachment might, for example, render the obsessive ineffectual, lame, and crippled by comorbidities. Just as legs grow bowed and soft in the absence of vitamin D and calcium, so the obsessive can become maimed in the absence of emotional support. Moreover, to recognize the proper scope and range of environmental influence, it is important to make the distinction between personality and personology (Rabin et al. 1989). Personology, the holistic study of persons and lives advanced by Murray (2007), Alexander (1990), and McAdams (2008), routinely divides persons into variously parsed levels, of which personality, reductively understood as trait patterns, is only one; other levels include identity and life narratives and the life course. Minding such personological distinctions, it is easier to understand how environmental forces might only exert "modest and subtle" (McAdams and Pals 2006) effects on the substrate of obsessive personality, even as environmental forces exert profound and pronounced effects on the obsessive person. For instance, without greatly swaying the core obsessive pattern, the culture which the obsessive absorbs during the acute phases of identity formation can greatly dictate the life course, informing the content of obsessive thought and the locus of obsessive labor.

In demoting parental influence to the periphery, it is obvious that this ecologically inspired evolutionary thesis breaks decidedly with psychoanalytically inspired etiological theory. The radicalism of this break is justified by the heritability of obsessive character, which simultaneously invalidates psychoanalytic theory while engendering evolutionary explanation. Discovering the genotype behind the obsessive phenotype makes obsessive character subject to natural and sexual selection. This model of obsessive origins is then consistent with a global evolutionary view of personality, holding that personality (1) is heritable, (2) has fitness consequences, (3) shows population variance as a result of adaptive diversification, and (4) is regulated by negative frequency-dependent balancing selection. As further work will show, the present theory better explains prevalence rates (Hertler 2014c), male-biased sex ratio, and trait coherence (Hertler 2014d) that are specific to obsessive personality. More than all this, the present evolutionary model is superior to psychoanalytic models 
because it is readily falsifiable. As previously noted (Hertler 2014c):

Obsessives should be far more prevalent in racial groups that have historically inhabited high latitude climates; for example, populations of Northern European descent should contain far higher obsessive prevalence rates than, for example, populations of Sub-Saharan African descent. So the present model is empirically tractable. Epidemiological investigation can categorically falsify etiological theory. If the present evolutionary model is correct, one should be able to create a biogeography of OCPD...Obsessive character should be most common in those ancestral populations residing between $40^{\circ}$ and $60^{\circ}$ north latitude. These are the world's most acutely seasonal lands, providing the reprieve of summer that can be used to prepare for the demands of winter.

\section{A Framework for Empirical Proof}

Not surprisingly, given the historical dominance of psychoanalytic explanation, no direct data, in the form of a global distribution of obsessives, has been sought or attained. As previously discussed to some degree (Hertler 2014c), the hypothesized relationship detailed above can be fully tested, though only after surmounting significant logistical and financial obstacles. In confirming or disconfirming a continuous positive relationship between northern latitude and obsessive prevalence, it is important to accurately measure both personality and ancestry. Challenges present in both respects. First, five-factor trait inventories, designed to measure normal personality variation, show a ceiling effect with regards to conscientiousness, making it difficult to differentiate moderate conscientiousness from the excessive conscientiousness found among obsessives (Haigler and Widiger 2001; Hertler 2014b). Administration of Haigler and Widiger's (2001) experimentally augmented conscientiousness items should be used to address this issue. Of greater concern, personality data gained via self-report, using, for example, the $N E O-P I-R$, is not valid when comparing between-group cross-national means, as will be discussed. As such, self-reported personality data should serve the limited function of culling large samples for potential obsessives, with confirmatory diagnosis being made via structured interview, using for instance, The Structured Clinical Interview for DSM-IV Axis II Personality Disorders. Selfreport and structured interviews should be triangulated with objective demographics; in this vein, the standards of life success put forth and measured by Ullrich et al. (2007), which were found to be significantly elevated among obsessive persons, can be used: high socioeconomic status, good income, and supervisory responsibilities at work, spacious living conditions, and home ownership (Hertler 2014c). Finally, a measure of temporal orientation, such as the Time Reference Inventory (Roos 1975), should be administered to capture this otherwise untapped obsessive personality variable.

With reference to latitude, present residence, of course, is an insufficient proxy of ancestral latitude because of the great amount of migration and gene flow that has occurred within modernity, and since industrialization. Self-reported nationality, though conveniently obtained via demographic inquiry, is subject to the genealogical knowledge of the respondent. More importantly, excessively large countries like China and peninsula-like countries like Italy subsume significant stretches of latitude and so may contain excessive intranational variation. This is likely to affect conscientiousness, because, for instance, Northern Italians appear more industrious than Southern Italians via cross-regional character ratings and objective economic measures (McCauley et al. 1999). Genetic assay, though unquestionably objective, may not be feasible. It might be best to simply measure skin color on a nonexposed body area. Not only can skin color be continuously quantified, it is objective and easily measurable. Furthermore, because melanism is a polygenetic trait subject to blending, it will elegantly control for racial admixture, and at the same time, because melanism mediates the relationship between insolation and vitamin D synthesis, it inherently serves as a marker of ancestral latitude which implicitly incorporates migratory history.

There is indirect data that can preliminarily confirm or disconfirm the present hypothesis and suggest whether or not funding and research should be directed towards developing a biogeographical obsessive distribution in the manner just specified. Trait distributions can be used in lieu of personality distributions. So while there is insufficient data to map global obsessive prevalence, there is sufficient data to map individual obsessive traits, particularly those three obsessive personality traits herein reviewed: future-oriented thought/time urgency, parsimoniousness, and conscientiousness.

\section{Latitudinal Variation in Time Urgency and Future-Oriented Thought}

First, those of African extraction, as compared to those of European extraction, are routinely found wanting on various measures of future orientation, such as delay of gratification (Zytkoskee et al. 1971; Price-Williams and Ramirez 1974), future planning (Ruiz and Padilla 1977), and future discounting (Poulos and Whittington 1999; Andrade and Petry 2014). Foreshortened future orientation can be observed behaviorally and statistically from planning a birth to preparing for death. African-American and Hispanic American teens are more likely than Caucasian Americans to be sexually active, but less likely to use contraceptives (Waddell et al. 2010) with teenaged pregnancy rates falling out on these same lines (Roxas 2008). Additionally, the higher proportional 
estimates of impulsivity, arrests (Fite et al. 2009), criminality (Petersilia 1983), incarceration (Brewer et al. 2014), and recidivism (Harer 1995; Harer and Steffensmeier 1996) among African-Americans and Hispanic Americans, as compared to Caucasian Americans, might also be taken as evidence of an evolved disposition towards foreshortened future orientation, especially since proportional excess of crime among those of African descent is recapitulated in other predominately Caucasian countries such as England and Canada (Rushton 1999). Further still, this trend persists internationally such that homicide rates, for instance, are highest in Southern Africa and lowest in Western Europe, which is part of an overall trend towards disproportionate violence within equatorial regions (Harrendorf and Heiskanen 2010). Restricted future orientation might also be gleaned through the persistently elevated high school dropout rate among African-American students (Heckman and LaFontaine 2010), who are also less apt to enroll in, or graduate from, college (McDaniel et al. 2011). Finally, future-oriented thought, as measured by completing written advance directives and assigning proxies, was lower among African and Hispanic Americans even when controlling for "gender, age, marital status, whether the decedent had children, income, education, religious preference, importance of religion, and frequency of attending religious services" (Burdsall 2014).

Just as ancestral latitude correlates positively with futureoriented thought, so it correlates positively with time urgency. Pace of life, as measured by walking speed, work speed, and clock accuracy, is fastest in Western European countries and generally correlated with cold climate and economic productivity (Levine and Norenzayan 1999). Specifically, "only Japan (4th) and Hong Kong (10th) intruded on" what was termed a "Western European monopoly" on time urgency. In turn, "...the slowest third of the list was composed of relatively nonindustrialized countries from Africa (Kenya, 22nd), Asia (China, 23rd), the Middle East (Jordan and Syria, 26th and 27th), and Latin America (El Salvador, Brazil, Indonesia, and Mexico, 28th through 31st, respectively)." Moreover, "consistent with the popular stereotype, the slowest speeds were in the nonindustrialized Third World": Brazil (where the stereotype of amanha holds that "whenever it is conceivably possible, people will put off the business of today until tomorrow"), Indonesia ("where the hour on the clock is often addressed as jam kerat, literally rubber time"), and Mexico ("the archetypical land of manana") (Levine and Norenzayan 1999). In conclusion, a fast pace of life is highly negatively correlated with temperature, such that "places with a faster pace of life were significantly more likely to have colder climates." Not only the data but also the explanation of it provided by the authors is in line with the present hypothesis: Warmer climates require fewer and less costly belongings, such as fewer clothes and simpler homes and so inhabitants of equatorial regions "should have less need for making every moment productive, leading to less value placed on people's time, resulting in a slower pace of life" (Levine and Norenzayan 1999). Moreover, interracial societies like the USA show this same pattern with, for example, AfricanAmericans and Mexican Americans having subcultures of time different from that of the "Anglo-American majority" (Levine 1997, page 10).

\section{Latitudinal Variation in Parsimony and Conservation}

Second, parsimony and conservation, as measured by monetary savings, also show strong biogeographical trends in line with the present hypothesis. In addition to insufficient governmental pensioning and social savings in Africa (Darkwa et al. 2002) and Latin America, personal savings rates are much lower as compared to northern industrialized countries (Edwards 1995, 1996). In reference to global averages, Latin American and Caribbean savings rates are low and those in Africa are still lower (Thanoon and Baharumshah 2012). These same trends are apparent domestically, such that $401 \mathrm{k}$ savings are higher for Caucasian Americans than African-Americans or Hispanic Americans (Madrian and Shea 2000). Moreover, this disparity cannot be entirely explained as an outgrowth of initial income disparity, as, for example, the African-American savings gap is more than twice that of the earning gap (Straight 2001). Also, this effect of lower Hispanic and African-American retirement savings, and retirement plan participation rates, is observed across all income levels; so while savings do rise with income, proportions remain similar (Authors 2012). Consequently, income disparity between Caucasian Americans and AfricanAmericans becomes more pronounced in retirement (Hogan et al. 1997). There is less investment in retirement, housing, and life insurance, which is attributed to "present-oriented attitudes" and a diminished ability to "delay gratification" (Xiao 2008, page 275). With inclinations to be "less proactive about saving for retirement," automatic enrollment is used to partially assuage these stark racial differences in futureoriented retirement savings (Authors 2012).

Even as the proportion of money saved is lower, its permanency is also lower: "Historically, African-Americans" and "to a lesser extent Hispanics" have "disproportionally eroded their account balances-or eliminated their accounts altogether" by "taking hardship withdrawals, taking out loans, and cashing out accounts upon terminating a job" (Authors 2012). What is more, "even when other contributing factors such as salary and age are held constant, African-Americans are $276 \%$, and Hispanics are $47 \%$, more likely to take hardship withdrawals than whites" (Authors 2012). Similarly, it is shown that across every income bracket, AfricanAmericans were twice as likely, or nearly so, to cash out a retirement plan rather than roll it over (Authors 2012). These findings highlight the tendency for African-Americans and 
Hispanic Americans to view retirement funds as a reserve, rather than a long-term savings vehicle (Authors 2012). In consequence, companies are called upon to be racially aware when structuring retirement investments (Millar 2003).

\section{Latitudinal Variation in Conscientiousness}

Finally, direct cross-cultural self-reported assays of conscientiousness decidedly do not show a positive relationship with latitude and thereby appear to categorically undermine this leg of the present hypothesis. Temperature is highly positively correlated $(0.61)$ with self-reported conscientiousness, such that, as temperature rises, so does conscientiousness. In turn, of course, this means that latitude and conscientiousness are inversely correlated (-0.41) (McCrae 2001; Allik and McCrae 2004), suggesting that migration out of Africa, and subsequent adaptation to northern latitudes, brought about a substantive decrease in conscientiousness. There are, however, some methodological and interpretive concerns: conceptual translational troubles (McCrae 2002), culturally idiosyncratic response sets (McCrae 2002), acquiescent responding (Hofstede and McCrae 2004), extreme responding (Johnson et al. 2005), nonequivalent literacy (Hofstede and McCrae 2004), response styles and selfpresentational motives (Allik and McCrae 2004; Geisinger 1994; van de Vijver and Leung 1997), violation of the uniformity assumption (McCrae 2001), and interpretive ambiguity (Campbell 1986), in addition to concerns about generalizability, cultural monocentrism, convenience sampling, scalar equivalence (van de Vijver and Leung 2001), metric equivalence, and full score equivalence (Poortinga et al. 2002). Yet, one of the most critical complaints of cross-national trait research is the systematic distortion imposed by the frameof-reference effect (Schmit et al. 1995), also known as the reference-group effect (Heine et al. 2002, 2008; Peng et al. 1997), in which respondents produce self-ratings relative to others in their culture, not relative to a heuristically intangible globalmean(Peruginiand Richetin 2007). Validity, of course, is a relative concept, such that a test can be valid for one application but not another. In this case, as per the frame-ofreference effect, trait measures produce valid within-group comparisons, butinvalid between-group comparisons(Heine et al. 2008; van de Vijver and Leung 2001; Cohen 2007). Cross-national misapplication therefore produces misleading data (Ashton 2007).

For all this, cross-national research does not, however, simply show cross-national similarity across traits, as implied by the frame-of-reference effect, but it shows a clear and strong, positive and consistent, relationship between temperature and conscientiousness that seems meaningful. The question then centers on how to best interpret this data. After diligent deliberation about methodological concerns, and after attempts to reconcile expectations with outcomes, those researchers originally producing this cross-national trait data, in the end, opted for a straightforward interpretation. These authors, following their data, arrived at the view that distance from the equator divested persons of conscientiousness (McCrae 2001; Allik and McCrae 2004; Hofstede and McCrae 2004; McCrae et al. 2007). Post hoc theoretical explanation for utterly unanticipated empirical findings followed. For example, it is thought that, after conscientiousness provides prosperity, "prosperity allows people to behave less conscientiously or more wastefully" (Hofstede and McCrae 2004). Similarly, in an effort to assimilate the positive association between temperature and conscientiousness, Kirkcaldy et al. (1998) state, "it may be that the work ethic, competitiveness, and concern about money are useful to drive economic activity but decline once it has been achieved. Indeed, it has been argued that the work ethic (and competitiveness) has within it seeds of its own destruction." After giving over their contradictory intuitions, McCrae et al. (2007) write: "The only reason to call their [cross-national trait data] accuracy into question is their failure to conform to our shared views of national character."

Aside from failing to conform to shared views of national character that have been historically (de Montesquieu 1900/ 1748) and currently (Perugini and Richetin 2007; Heine et al. 2008) avowed, there are three more compelling reasons to reject any straightforward interpretation of cross-national conscientiousness data. First, the substantial heritability of traits such as conscientiousness is well established by behavioral genetic research (Bergeman et al. 1993), a fact that is reiterated even in the midst of presenting cross-national trait findings, as when Hofstede and McCrae (2004) note that traits are "rooted in biology," and "largely impervious to life experience." Given this, it should not follow that constitutionally conscientious persons lose their conscientiousness once its objectives are attained. In other words, genetically undergirded conscientious behavior should not "contain the seeds of its own destruction"; it should not dissipate in consequence of an environmental factor, in this case success.

Second, Heine et al. (2008) assert that Gross Domestic Product (GDP), pace of life, and mean national longevity are objective measures of national conscientiousness superior to cross-national comparisons of self-reports. Yet, as per selfreported cross-national comparisons, each of these three variables shows a strong, negative correlation with conscientiousness (McCrae 2001; Allik and McCrae 2004). Illogically, cross-national self-reported measures of conscientiousness (McCrae 2001), competitiveness (Kirkcaldy et al. 1998), and work ethic all inversely related to GDP, with high-per-capitaGDP northerly nations like Japan (16.7), Germany (17.8), and France (18.8) falling far behind low-per-capita-GDP southerly nations like Brazil (21.1), Mexico (21.3), and Egypt (21.9) (Lynn and Martin 1995). Again, perfectly contrary to the straightforward interpretation of cross-national trait data, pace 
of life, as measured by walking speed, work speed, and clock accuracy, is fastest in Western European countries and slowest in "economically undeveloped countries" of the nonindustrialized Third World and as before mentioned, those very slowest were in three countries popularly associated with a relaxed pace of life: Brazil, Indonesia, and Mexico (Levine and Norenzayan 1999). In reaction, Allik and McCrae (2004) state, "the strong association of average temperature with conscientiousness is puzzling; it does not fit well with findings that the pace of life is slower in tropical countries (Levine and Norenzayan 1999)." Finally, longevity, repeatedly associated with elevated conscientiousness (Bogg and Roberts 2004, 2013; McCann 2005; Kern and Friedman 2008; Costanzo 2014), also positively correlates with latitude, as observed by racial disparities in life span (Murray et al. 2006) and degenerative maladies like cardiovascular disease (Mensah et al. 2005) and cancer (Jemal et al. 2006). What is more, this effect is likely related, at least in part, to evolved life history variation associated with ancestral latitude (Rushton 2000; Meeûs 2000).

The case of the hardworking, fast-paced, and long-lived Japanese neatly highlights the paradoxical findings of crossnational research: Via self-report, McCrae (2001) found Japan to be the least conscientious nation of more than 30 sampled, a fact which belies the massive government campaigns which ineffectually attempt to reduce the amount of hours worked and increase the amount of vacation time taken. Along with a very high-per-capita GDP, fast pace of life, average annual clock hours estimated at 2159 annually per employee, and $73 \%$ of the labor force working more than $40 \mathrm{~h}$ weekly, sociological evidence suggests that the "Japanese dedication to work can be dazzling" (Levine 1997, page 170). In reaction to these paradoxical findings, McCrae (2001) assembled a panel of more than 25 expert judges for validation purposes, essentially none of whom supported his cross-national data.

Third, international trait data is directly contrary to intranational trait data. In other words, just as expected, within groups, self-reported conscientiousness is reliably, strongly, and positively related to a wealth of objective, quantifiable, concrete, and meaningful correlates. For instance, the positive association between job performance and conscientiousness (Digman 1989; Smith 1967; Wiggins et al. 1969; Viswesvaran et al. 1996; Salgado 1997; Tett et al. 1991) holds across various occupations, such as professionals, police, managers, and sales, whether measured by performance ratings, productivity data, training performance ratings, salary level, turnover status change, or tenure (Barrick and Mount 1991). This shows that conscientiousness, an internal personality trait, does reliably relate to external, measurable success. What is surprising is that within the self-same articles, the strongest contrasts can exist between traditionally derived within-group trait data and cross-national or cross-racially compared means. The research of Letkiewicz and Fox (2014) concisely illustrates the case: After reviewing well-cited literature demonstrating that, within groups, conscientiousness is positively associated with longevity, physical health, occupational attainment, job performance, marriage stability, drug abstinence, and asset accumulation, Letkiewicz and Fox (2014) report that African-Americans within their sample had the highest mean self-reported levels of conscientiousness, while Caucasian Americans had the lowest. Though when one looks at their listed objective correlates of conscientiousness, it would suggest the diametrically opposite findings: With the possible exception of drug use, Caucasians surpass African-Americans across these many correlates of conscientiousness: longevity (Rushton 2000), aged physical health (Haas et al. 2012), occupational attainment (Wilson 2007), educational attainment (McDaniel et al. 2011), employment (Blair and Fichtenbaum 2012), marriage rate and marital stability (Sweeney and Phillips 2004), and asset accumulation (Oliver and Shapiro 1995; Wilson 2007).

Because a straightforward interpretation of cross-national data (1) has no defensible theoretical interpretation consonant with the biology of conscientiousness; (2) is exactly opposite objective, cross-national correlates of conscientiousness, such as GDP; (3) and is consistently contrary to traditional, valid application of trait research, it should be rejected; and not only rejected, but fully inverted as follows: The higher a nation's self-reported conscientiousness ratings are, the lower is their actual conscientiousness. Without digressing far into explanations, it may be that a variant of the Frame of Reference effect is operating, such that the more conscientious one's reference group is in reality, the less conscientious each individual feels by comparison, and vice versa. Operatively, rather than creating homogeneity amidst cross-national trait data, this effect would systematically, and inversely, exaggerate actual cross-national differences in conscientiousness, as it is seen. In this way, not only the objective data but also the cross-national conscientiousness ratings themselves can be taken as evidence in support of a strongly positive relationship between latitude and conscientiousness, thereby adding a third point of supporting evidence for the overall hypothesis that obsessive psychology evolved of northerly ecology.

So, though there is as of yet no direct evidence that the global obsessive phenotype is concentrated within ancestral inhabitants of high-latitude regions, there is evidence that constituent traits are, conscientiousness not excluded. Suggestively, there is often overlap in the literature among these three obsessive traits, so that when researching time orientation, one finds a discussion of national productivity, work ethic (Levine and Norenzayan 1999), and conscientiousness (Kirkcaldy et al. 2001); when researching conscientiousness, one finds information on pace of life (Allik and McCrae 2004), future consequences (Gick 2014), and asset accumulation (Letkiewicz and Fox 2014); and when researching 
parsimoniousness, one finds information on future orientation (Xiao 2008). This supports the suggestion that obsessive traits are more adaptive in aggregate than in isolation and so cohere within individuals, as found in the obsessive personality complex. In sum, because the present etiology of obsessive character better fits the data, is falsifiable, and has preliminary support, research efforts should be directed away from relational dynamics and towards the scientific study of obsessive personality in terms of genetics, cognition, demography, ecology, mating, and physiology.

\section{References}

Alexander, I. E. (1990). Personology: method and content in personality assessment and psychobiography. Durham: Duke University Press.

Allik, J., \& McCrae, R. R. (2004). Toward a geography of personality traits patterns of profiles across 36 cultures. Journal of CrossCultural Psychology, 35, 13-28.

American Psychiatric Association. (2000). Diagnostic and statistical manual of mental disorders (4th edition, text revision). Washington, DC: Author.

American Psychiatric Association. (2013). Diagnostic and statistical manual of mental disorders (5th ed.). Washington, DC: Author.

Andrade, L. F., \& Petry, N. M. (2014). White problem gamblers discount delayed rewards less steeply than their African American and Hispanic counterparts. Psychology of Addictive Behaviors, 28, 599-606.

Ashton, M. C. (2007). Self-reports and stereotypes: a comment on McCrae et al. European Journal of Personality, 21, 983-986.

Authors. (2012). 401 (k) plans in living color: a study of 401 (k) savings disparities across racial and ethnic groups. The Ariel/aon Hewitt Study. (https://www.arielinvestments.com/images/stories/PDF/ ariel-aonhewitt-2012.pdf).

Barrick, M. R., \& Mount, M. K. (1991). The big five personality dimensions and job performance: a meta-analysis. Personnel Psychology, $44,1-26$.

Bar-Yosef, O., \& Belfer-Cohen, A. (2000). Early human dispersals: the unexplored constraint of African diseases. Early Humans at the Gates of Europe, 79-86.

Bar-Yosef, O., \& Belfer-Cohen, A. (2001). From Africa to Eurasia - early dispersals. Quaternary International, 75, 19-28.

Bergeman, C. S., Chipuer, H. M., Plomin, R., Pedersen, N. L., McClearn, G. E., Nesselroade, J. R., Costa, P. T., Jr., \& McCrae, R. R. (1993). Genetic and environmental effects on openness to experience, agreeableness, and conscientiousness: an adoption/twin study. Journal of Personality, 61, 159-179.

Blair, J. P., \& Fichtenbaum, R. H. (2012). Five changing black employment patterns. In G. C. Galster \& E. W. Hill (Eds.), The metropolis in black and white: place, power and polarization (pp. 72-92). Piscataway: Transaction.

Blaney, P. H., \& Millon, T. (2009). Oxford textbook of psychopathology. New York: Oxford University Press.

Bogg, T., \& Roberts, B. W. (2004). Conscientiousness and health-related behaviors: a meta-analysis of the leading behavioral contributors to mortality. Psychological Bulletin, 130, 887-919.

Bogg, T., \& Roberts, B. W. (2013). The case for conscientiousness: evidence and implications for a personality trait marker of health and longevity. Annals of Behavioral Medicine, 45, 278-288.
Brewer, R. A., Magnus, M., Kuo, I., Lei, W., Ting-Yuan, L., \& Mayer, K. H. (2014). The high prevalence of incarceration history among black men who have sex with men in the United States: associations and implications. American Journal of Public Health, 104, 448- 454.

Brockman, D. K. (2005). What do studies of seasonality in primates tell us about human evolution? In D. K. Brockman \& C. P. van Schaik (Eds.), Seasonality in primates: studies of living and extinct human and non-human primates (pp. 543-570). New York: Cambridge University Press.

Burdsall, T. L. (2014). The effects of race, socioeconomic status, and religion on formal end-of-life planning. Dissertation Abstracts International Section A, 74 .

Bush, A. O., Fernandez, J. C., Esch, G. W., \& Seed, J. R. (2001). Parasitism: the diversity and ecology of animal parasites. New York: Cambridge University Press.

Campbell, D. T. (1986). Science's social system of validity-enhancing collective belief change and the problems of the social sciences. In D. W. Fiske (Ed.), Metatheory in social science: pluralisms and subjectivities (pp. 108-135). Chicago: Chicago University Press.

Cavalli-Sforza, L., Menozzi, P., \& Piazza, A. (1994). The history and geography of human genes. Princeton: Princeton University Press.

Cochran, G., \& Harpending, H. (2009). The 10,000 year explosion: how civilization accelerated human evolution. New York: Basic Books.

Cohen, D. (2007). Methods in cultural psychology. In S. Kitayama \& D. Cohen (Eds.), Handbook of cultural psychology (pp. 196-236). New York: Guilford.

Costanzo, P. R. (2014). Conscientiousness in life course context: a commentary. Developmental Psychology, 50, 1460-1464.

Cox, C. B., \& Moore, P. D. (2010). Biogeography: an ecological and evolutionary approach (8th ed.). Hoboken: Wiley.

Darkwa, O. K., Mazibuko, F. N. M., \& Candidate, P. D. (2002). Population aging and its impact on elderly welfare in Africa. The International Journal of Aging and Human Development, 54, 107123.

Darwin, C. (1859/2005). On natural selection. New York: Penguin Books.

de Montesquieu, B. (1900/1748). The spirit of the laws [1748] (Trans: Nugent, T.). New York: Colonial.

Deary, I. J., Peter, A., Austen, E., \& Gibson, G. (1998). Personality traits and personality disorders. British Journal of Psychology, 89, 647661.

Digman, J. M. (1989). Five robust trait dimensions: development, stability, and utility. Journal of Personality, 57, 195-214.

Dunbar, R. I. (1992). Time: a hidden constraint on the behavioural ecology of baboons. Behavioral Ecology and Sociobiology, 31, $35-49$.

Edwards, S. (1995) Why are saving rates so different across countries? An international comparative analysis. NBER Working Paper No. 5097.

Edwards, S. (1996). Why are Latin America's savings rates so low? An international comparative analysis. Journal of Development Economics, 51, 5-44.

Eskedal, G. A., \& Demitri, J. M. (2006). Etiology and treatment of cluster C personality disorders. Journal of Mental Health Counseling, 28, $1-17$.

Feldhamer, G. A., Drickamer, L. C., Vessey, S. H., Merritt, J. F., \& Krajewski, C. (2007). Mammalogy: adaptation, diversity, ecology (3rd ed.). Baltimore: Johns Hopkins University Press.

Ferro-Luzzi, A., \& Branca, F. (1993). Nutritional seasonality: the dimensions of the problem.

Figueredo, A. J., Wolf, P. S. A., Gladden, P. R., Olderbak, S., Andrzejczak, D. J., \& Jacobs, W. J. (2011). Ecological approaches to personality. In D. M. Buss \& P. H. Hawley (Eds.), The evolution of personality and individual differences (pp. 210-239). New York: Oxford University Press. 
Fite, P. J., Wynn, P., \& Pardini, D. A. (2009). Explaining discrepancies in arrest rates between Black and White male juveniles. Journal of Consulting and Clinical Psychology, 77, 916.

Fleagle, J. G. (2013). Primate adaptation and evolution (3rd ed.). San Diego: Academic.

Foley, R. A. (1993). The influence of seasonality on hominid evolution. In S. J. Ulijaszek \& S. S. Strickland (Eds.), Seasonality and human ecology: 35th symposium volume of the society for the study of human biology (pp. 17-37). New York: Cambridge University Press.

Fossati, A., Beauchaine, T. P., Grazioli, F., Borroni, S., Carretta, I., De Vecchi, C., Cortinovis, F., Danelli, E., \& Maffei, C. (2006). Confirmatory factor analyses of DSM- IV cluster C personality disorder. Journal of Personality Disorders, 20, 186-203.

Freud, S. (1908/1959). Character and anal eroticism. In J. Strachey (Ed.), The complete psychological works of Sigmund Freud, standard edition. London: Hogarth.

Furnham, A., \& Crump, J. (2005). Personality traits, types and disorders: an examination of the relationship between three self-report measures. European Journal of Personality, 19, 167-184.

Gaston, K. J. (2009). Geographic range. In S. A. Levin (Ed.), The Princeton guide to ecology (pp. 87-92). Princeton: Princeton University Press.

Gat, A. (2008). War in human civilization. New York: Oxford University Press.

Gay, P. (1989). The Freud reader. New York: Norton \& Company.

Geisinger, K. F. (1994). Cross-cultural normative assessment: translation and adaptation issues influencing the normative interpretation of assessment instruments. Psychological Assessment, 6, 304-312.

Gibbs, N. A. \& Oltmanns, T. F. (1995). The relation between obsessivecompulsive personality traits and subtypes of compulsive behavior. Journal of Anxiety disorders, 9, 397-410.

Gick, M. (2014). An exploration of interactions between conscientiousness and consideration of future consequences on healthy eating. Personality and Individual Differences, 66, 181-187.

Gosling, S. D., \& Mehta, P. H. (2013). Personalities in a comparative perspective: what do human psychologists glean from animal personality studies? In C. Carere \& D. Maestripieri (Eds.), Animal personalities: behavior, physiology, and evolution (pp. 124-145). Chicago: University of Chicago Press

Haas, S. A., Krueger, P. M., \& Rohlfsen, L. (2012). Race/ethnic and nativity disparities in later life physical performance: the role of health and socioeconomic status over the life course. The Journals of Gerontology Series B: Psychological Sciences and Social Sciences, 67, 238-248.

Haigler, E. D., \& Widiger, T. A. (2001). Experimental manipulation of NEO-PI-R items. Journal of Personality Assessment, 77, 339-358.

Harcourt, A. H. (2012). Human biogeography. Berkley and Los Angeles: University of California Press.

Harer, M. D. (1995). Recidivism among federal prisoners released in 1987. Journal of Correctional Education, 46, 98-128.

Harer, M. D., \& Steffensmeier, D. J. (1996). Race and prison violence. Criminology, 34, 323-355.

Harrendorf, S., \& Heiskanen, M. (2010). International statistics on crime and justice. In S. Malby (Ed.), European Institute for Crime Prevention and Control, affiliated with the United Nations (HEUNI).

Heckman, J. J., \& LaFontaine, P. A. (2010). The American high school graduation rate: trends and levels. The Review of Economics and Statistics, 92(2), 244-262.

Heine, S. J., Lehman, D. R., Peng, K., \& Greenholtz, J. (2002). What's wrong with cross-cultural comparisons of subjective Likert scales?: the reference-group effect. Journal of Personality and Social Psychology, 82, 903-918.
Heine, S. J., Buchtel, E. E., \& Norenzayan, A. (2008). What do crossnational comparisons of personality traits tell us? The case of conscientiousness. Psychological Science, 19, 309-313.

Hemingway, C. A., \& Bynum, N. (2005). The influence of seasonality on primate diet and ranging. In D. K. Brockman \& C. P. van Schaik (Eds.), Seasonality in primates: studies of living and extinct human and non-human primates (pp. 57-104). New York: Cambridge University Press.

Hertler, S. C. (2013). Understanding obsessive compulsive personality disorder: reviewing the specificity and sensitivity of DSM-IV diagnostic criteria. Sage Open, 3, 1-10.

Hertler, S. C. (2014a). A review and critique of obsessive-compulsive personality disorder etiologies: reckoning with heritability estimates. Europe's Journal of Psychology, 10, 168-184.

Hertler, S. C. (2014b). The continuum of conscientiousness: the antagonistic interests among obsessive and antisocial personalities. Polish Psychological Bulletin, 45, 52-63.

Hertler, S. C. (2014c). Obsessive compulsive personality disorder epidemiology: the clinical, etiological and biogeographical implications of obsessive prevalence. Unpublished manuscript currently in review: Psychological Writings.

Hertler, S. C. (2014d). The evolutionary logic of the obsessive trait complex: obsessive compulsive personality disorder as a complementary behavioral syndrome. Accepted and in press: Psychological Thought.

Hofstede, G., \& McCrae, R. R. (2004). Personality and culture revisited: linking traits and dimensions of culture. Cross-Cultural Research, $38,52-88$

Hogan, R., Kim, M., \& Perrucci, C. (1997). Racial inequality in men's employment and retirement earnings. The Sociological Quarterly, $38,431-438$.

Hummelen, B., Wilberg, T., Pedersen, G., \& Karterud, S. (2008). The quality of the DSM-IV obsessive-compulsive personality disorder construct as a prototype category. Journal of Nervous and Mental Disease, 196, 446-455. In S. J. Ulijaszek \& S. S. Strickland (Eds.), Seasonality and human ecology: 35th symposium volume of the society for the study of human biology (pp. 149-165). New York: Cambridge University Press.

Jemal, A., Siegel, R., Ward, E., Murray, T., Xu, J., Smigal, C., \& Thun, M. J. (2006). Cancer statistics, 2006. CA: a Cancer Journal for Clinicians, 56, 106-130. Journal of Personality Disorders, 18, 467-478.

Johnson, T., Kulesa, P., Cho, Y. I., \& Shavitt, S. (2005). The relation between culture and response styles: evidence from 19 countries. Journal of Cross-Cultural Psychology, 36, 264-277.

Kern, M. L., \& Friedman, H. S. (2008). Do conscientious individuals live longer? A quantitative review. Health Psychology, 27, 505-512.

Kirkcaldy, B. D., Furnham, A., \& Martin, T. (1998). National differences in personality, socio-economic, and work-related attitudinal variables. European Psychologist, 3, 255-262.

Kirkcaldy, B., Furnham, A., \& Levine, R. (2001). Attitudinal and personality correlates of a nation's pace of life. Journal of Managerial Psychology, 16, 20-34.

Lehman, S. M., \& Fleagle, J. G. (2006). Biogeography and primates: a review. In S. M. Lehman \& J. G. Fleagle (Eds.), Primate biogeography: progress and prospects (pp. 1-58). New York: Springer Science.

Letkiewicz, J. C., \& Fox, J. J. (2014). Conscientiousness, financial literacy, and asset accumulation of young adults. Journal of Consumer Affairs, 48, 274-300.

Levine, R. (1997). A geography of time: the temporal misadventures of a social psychologist. New York: Basic Books.

Levine, R. V., \& Norenzayan, A. (1999). The pace of life in 31 countries. Journal of Cross-Cultural Psychology, 30, 178-205. 
Li, Z., \& Rogers, E. (2004). Habitat quality and activity budgets of whiteheaded langurs in Fusui, China. International Journal of Primatology, 25, 41-54.

Luciano, M., Wainwright, M. A., Wright, M. J., \& Martin, N. G. (2006). The heritability of conscientiousness facets and their relationship to IQ and academic achievement. Personality and Individual Differences, 40, 1189-1199.

Lynam, D. R., \& Widiger, T. A. (2001). Using the five-factor model to represent the $D S M-I V$ personality disorders: an expert consensus approach. Journal of Abnormal Psychology, 110, 401-412.

Lynn, R., \& Martin, T. (1995). National differences for thirty-seven nations in extraversion, neuroticism, psychoticism and economic, demographic and other correlates. Personality and Individual Differences, 19, 403-406.

MacArthur, R. H. (1972). Geographical ecology: patterns in the distribution of species. New York: Harper \& Row.

Madrian, B. C. \& Shea, D. F. (2000). The power of suggestion: Inertia in 401 (k) participation and savings behavior (No. w7682). National Bureau of Economic Research.

Mataix-Cols, D., Frost, R. O., Pertusa, A., Clark, L., Saxena, S., Leckman, J. F., Stein, D. J., Matsunaga, H., \& Wilhelm, S. (2010). Hoarding disorder: a new diagnosis for DSM-V? Depression and Anxiety, 27, 556-572.

McAdams, D. P. (2008). The person: an introduction to the science of personality psychology. New York: Wiley.

McAdams, D. P., \& Pals, J. L. (2006). A new big five: fundamental principles for an integrative science of personality. American Psychologist, 61, 204-217.

McCann, S. J. H. (2005). Longevity, Big five personality factors, and health behaviors: presidents from Washington to Nixon. Journal of Psychology, 139, 273-286.

McCauley, C., Ottati, V., \& Lee, Y. (1999). National differences in economic growth: the role of personality and culture. In Y. Lee, C. R. McCauley, \& Draguns (Eds.), Personality and person perception across cultures (pp. 85-102). Hillsdale: Erlbaum.

McCrae, R. R. (2001). Trait psychology and culture: exploring intercultural comparisons. Journal of Personality, 69, 819-846.

McCrae, R. R. (2002). Cross-cultural research on the five-factor model of personality. Online Readings in Psychology and Culture, 4, 1-12.

McCrae, R. R., Terracciano, A., Realo, A., \& Allik, J. (2007). On the validity of culture-level personality and stereotype scores. European Journal of Personality, 21(8), 987-991.

McDaniel, A., DiPrete, T. A., Buchmann, C., \& Shwed, U. (2011). The Black gender gap in educational attainment: historical trends and racial comparisons. Demography, 48, 889-914.

Mealey, L. (1995). The sociobiology of sociopathy: an integrated evolutionary model. Behavioral and Brain Sciences, 18, 523-599.

Meeûs, D. (2000). Human longevity at the cost of reproductive success: evidence from global data. Journal of Evolutionary Biology, 13, 409-414.

Mellars, P. (2006). Why did modern human populations disperse from Africa $c a$. 60,000 years ago? A new model. Proceedings of the National Academy of Sciences, 103, 9382-9386.

Ménard, N., Motsch, P., Delahaye, A., Saintvanne, A., Le Flohic, G., Dupé, S., Vallet, D., Qarro, M., \& Pierre, J. (2013). Effect of habitat quality on the ecological behaviour of a temperate-living primate: time-budget adjustments. Primates, 54, 217-228.

Menon, S., \& Poirier, F. E. (1996). Lion-tailed macaques (Macaca silenus) in a disturbed forest fragment: activity patterns and time budget. International Journal of Primatology, 17, 969-985.

Mensah, G. A., Mokdad, A. H., Ford, E. S., Greenlund, K. J., \& Croft, J. B. (2005). State of disparities in cardiovascular health in the United States. Circulation, 111, 1233-1241.

Millar, M. (2003). DTI urges leading firms to take positive action. Personnel Today, 3.
Millon, T., \& Davis, R. D. (1996). Disorders of personality DSM-IV and beyond. New York: Wiley.

Morey, L. C., Warner, M. B., Shea, M. T., Gunderson, J. G., Sanislow, C. A., Grilo, C., Skodol, A. E., \& McGlashan, T. H. (2003). The representation of four personality disorders by the schedule for nonadaptive and adaptive personality dimensional model of personality. Psychological Assessment, 15, 326-332.

Morrogh-Bernard, H. C., et al. (2009). Orangutan activity budgets and diet. In S. A. Wich, S. S. U. Atmoko, T. M. Setia, \& C. P. van Schaik (Eds.), Orangutans: geographic variation in behavioral ecology and conservation (pp. 119-134). New York: Oxford University Press.

Murray, H. A. (2007). Explorations in personality. New York: Oxford University Press.

Murray, C. J., Kulkarni, S. C., Michaud, C., Tomijima, N., Bulzacchelli, M. T., Iandiorio, T. J., \& Ezzati, M. (2006). Eight Americas: investigating mortality disparities across races, counties, and racecounties in the United States. PLoS Medicine, 3(9), e260.

Nettle, D. (2006). The evolution of personality variation in humans and other animals. American Psychologist, 61, 622-631.

Oliver, M. L., \& Shapiro, T. M. (1995). Black wealth/white wealth. Urbana: University of Illinois Press.

Panter-Brick, C. (1993). Seasonal organization of work patterns. In S. J. Ulijaszek \& S. S. Strickland (Eds.), Seasonality and human ecology: 35th symposium volume of the society for the study of human biology (pp. 220-234). New York: Cambridge University Press.

Peng, K., Nisbett, R. E., \& Wong, N. Y. C. (1997). Validity problems comparing values across cultures and possible solutions. Psychological Methods, 2, 329-344.

Perin, N. (2009). Dispersal. In S. A. Levin (Ed.), The Princeton guide to ecology (pp. 45-50). Princeton: Princeton University Press.

Perugini, M., \& Richetin, J. (2007). In the land of the blind, the one-eyed man is king. European Journal of Personality, 21, 977-981.

Petersilia, J. (1983). Racial disparities in the criminal justice system. Santa Monica: Rand Corporation.

Pfennig, D. W., \& Pfennig, K. S. (2012). Evolution's wedge: competition and the origins of diversity. Berkeley: University of California Press.

Pfohl, B., \& Blum, N. (1991). Obsessive-compulsive personality disorder: a review of available data and recommendations for DSM-IV. Journal of Personality Disorders, 5, 363-375.

Phillimore, A. (2014). Geography, range evolution, and speciation. In J. B. Losos (Ed.), The Princeton guide to evolution (pp. 504-511). Princeton: Princeton University Press.

Phillips, B. L., Kelehear, C., Pizzatto, L., Brown, G. P., Barton, D., \& Shine, R. (2010). Parasites and pathogens lag behind their host during periods of host range advance. Ecology, 91, 872-881.

Pollak, J. M. (1979). Obsessive-compulsive personality: a review. Psychological Bulletin, 86, 225-241.

Pollak, J. M. (1987). Obsessive-compulsive personality: theoretical and clinical perspectives and recent research findings. Journal of Personality Disorders, 1, 248-262.

Poortinga, Y. H., van De Vijver, F. J., \& van Hemert, D. A. (2002). Crosscultural equivalence of the big five. In R. R. McCrae \& J. Allik (Eds.), The five-factor model of personality across cultures (pp. 281-302). Springer US.

Poulos, C., \& Whittington, D. (1999). Individuals' time preferences for life-saving programs: results from six less developed countries. Department of Environmental Sciences and Engineering, University of North Carolina at Chapel Hill. (http://core.kmi.open. ac.uk/download/pdf/6268181.pdf).

Price-Williams, D. R., \& Ramirez, M. (1974). Ethnic differences in delay of gratification. The Journal of Social Psychology, 93, 23-30.

Rabin, A. I., Zucker, R. A., Emmons, R. A., \& Frank, S. (1989). Studying persons and lives. New York: Springer Publishing Company.

Reich, D. E., \& Goldstein, D. B. (1998). Genetic evidence for a Paleolithic human population expansion in Africa. Proceedings of 
the National Academy of Sciences of the United States of America, 95, 8119-8123.

Reichborn-Kjennerud, T., Czajkowski, N., Neale, M. C., Orstavik, R. E., Torgersen, S., Tambs, K., Røysamb, E., Harris, J., \& Kendler, K. S. (2007). Genetic and environmental influences on dimensional representations of DSM-IV cluster C personality disorders: a population-based multivariate twin study. Psychological Medicine, 37, 645-653.

Roberts, B. W., Chernyshenko, O. S., Stark, S., \& Goldberg, L. R. (2005). The structure of conscientiousness: an empirical investigation based on seven major personality questionnaires. Personnel Psychology, $58,103-139$.

Roos, P. (1975). Time reference inventory. Educational Testing Service.

Roxas, K. (2008). Keeping it real and relevant: providing a culturally responsive education to pregnant and parenting teens. Multicultural Education, 15, 2-9.

Ruiz, R. A., \& Padilla, A. M. (1977). Counseling Latinos. The Personnel and Guidance Journal, 55, 401-408.

Rushton, P. J. (1999). Ethnic differences in temperament. In Y. Lee, C. R. McCauley, \& J. G. Draguns (Eds.), Personality and person perception across cultures (pp. 45-63). Mahwah: Lawrence Erlbaum.

Rushton, J. P. (2000). Race, evolution, and behavior: a life history perspective (3rd ed.). Port Huron: Charles Darwin Research Institute.

Saj, T., Sicotte, P., \& Paterson, J. D. (1999). Influence of human food consumption on the time budget of vervets. International Journal of Primatology, 20, 977-994.

Salgado, J. F. (1997). The five factor model of personality and job performance in the European Community. Journal of Applied Psychology, 82, 30

Salzman, L. (1985). Treatment of the obsessive personality. Northvale: Jason Aronson.

Samuel, D. B., \& Widiger, T. A. (2009). A meta-analytic review of the relationship between the five-factor model and the DSM-IV-TR personality disorders: a facet level analysis. Clinical Psychology Review, 28, 1326-1342.

Samuel, D. B., \& Widiger, T. A. (2010). A comparison of obsessivecompulsive personality disorder scales. Journal of Personality Assessment, 92, 232-240.

Samuel, D. B., \& Widiger, T. A. (2011). Conscientiousness and obsessive-compulsive personality disorder. Personality Disorders: Theory, Research, and Treatment, 2, 161-174.

Schluter, D. (2000). The ecology of adaptive radiation: Oxford series in ecology and evolution. New York: Oxford University Press.

Schluter, D. (2014). Speciation and macroevolution. In J. B. Losos (Ed.), The Princeton guide to evolution (pp. 483-487). Princeton: Princeton University Press.

Schmid-Hempel, P. (2011). Evolutionary parasitology: the integrated study of infections, immunology, ecology, and genetics. New York: Oxford University Press.

Schmit, M. J., Ryan, A. M., Stierwalt, S. L., \& Powell, A. B. (1995). Frame-of-reference effects on personality scale scores and criterionrelated validity. Journal of Applied Psychology, 80, 607.

Seedat, S., \& Stein, D. J. (2002). Hoarding in obsessive-compulsive disorder and related disorders: a preliminary report of 15 cases. Psychiatry and Clinical Neurosciences, 56, 17-23.

Shapiro, D. (1999). Neurotic styles. New York: Basic Books.

Shea, J. J. (2007). Behavioral differences between middle and upper paleolithic Homo sapiens in the East Mediterranean Levant: the roles of intraspecific competition and dispersal from Africa. Journal of Anthropological Research, 63, 449-488.

Sherrat, T. N., \& Wilkinson, D. M. (2009). Big questions in ecology and evolution. New York: Oxford University Press.

Shryock, A., \& Smail, D. L. (2011). Deep history: the architecture of past and present. Los Angeles: University of California Press.
Simondon, K. B., Benefice, E., Simondon, F., Delaunay, V., \& Chahnazarian, A. (1993). Seasonal variation in nutritional status of adults and children in rural Senegal. In S. J. Ulijaszek \& S. S. Strickland (Eds.), Seasonality and human ecology: 35th symposium volume of the society for the study of human biology (pp. 166-183). New York: Cambridge University Press.

Smith, G. M. (1967). Usefulness of peer ratings of personality in educational research. Educational and Psychological Measurement, 27, 967-984.

Smith, E. A., \& Winterhalder, B. (1992). Evolutionary ecology and human behavior. New York: Aldine De Gruyter.

Stearns, S. C., \& Hoekstra, R. F. (2005). Evolution: an introduction (2nd ed.). New York: Oxford University Press.

Straight, R. L. (2001). Survey of consumer finances: asset accumulation differences by race. The Review of Black Political Economy, 29, 6781.

Strulik, H. (2008). Degrees of development: how geographic latitude sets the pace of industrialization and demographic change. Discussion papers-School of Economics and Management of the Hanover Leibniz University, No. 384.

Sweeney, M. M., \& Phillips, J. A. (2004). Understanding racial differences in marital disruption: recent trends and explanations. Journal of Marriage and Family, 66, 639-650.

Tett, R. P., Jackson, D. N., \& Rothstein, M. (1991). Personality measures as predictors of job performance: a meta-analytic review. Personnel Psychology, 44, 703-742.

Thanoon, M. A. M., \& Baharumshah, A. Z. (2012). Comparing savings behavior in Asia and Latin America: the role of capital inflows and economic growth. The Journal of Developing Areas, 46, 113-131.

Thorington, R. W., Jr., Koprowski, J. L., Steele, M. A., \& Whatton, J. F. (2012). Squirrels of the world. Baltimore: Johns Hopkins University Press.

Torgersen, S., Lygren, S., Øien, P. A., Skre, I., Onstad, S., Edvardsen, J., Tambs, K., \& Kringlen, E. (2000). A twin study of personality disorders. Comprehensive Psychiatry, 41, 416-425.

Ulijaszek, S. J., \& Strickland, S. S. (1993). Seasonality and human ecology: 35th symposium volume of the society for the study of human biology. New York: Cambridge University Press.

Ullrich, S., Farrington, D. P., \& Coid, J. W. (2007). Dimensions of DSMIV personality disorders and life-success. Journal of Personality Disorders, 21, 657-663.

van de Vijver, F. J. R., \& Leung, K. (1997). Methods and data analysis of comparative research. In J. W. Berry, Y. H. Poortinga, \& J. Pandey (Eds.), Handbook of cross-cultural psychology: vol 1: theory and method (pp. 217-253). Needham Heights: Allyn \& Bacon.

van de Vijver, F., \& Leung, K. (2001). Personality in cultural context: methodological issues. Journal of Personality, 69, 1007-1031.

Van Doorn, A. C., O'Riain, M. J., \& Swedell, L. L. (2010). The effects of extreme seasonality of climate and day length on the activity budget and diet of semi-commensal chacma baboons (Papio ursinus) in the Cape Peninsula of South Africa. American Journal of Primatology, $72,104-112$

Vander Wall, S. B. (1990). Food hoarding in animals. Chicago: Chicago University Press.

Villemarette-Pittman, N. R., Stanford, M. S., Greve, K. W., Houston, R. J., \& Mathias, C. W. (2004). Obsessive compulsive personality disorder and behavioral disinhibition. The Journal of Psychology, $138,5-22$.

Viswesvaran, C., Ones, D. S., \& Schmidt, F. L. (1996). Comparative analysis of the reliability of job performance ratings. Journal of Applied Psychology, 81, 557.

Waddell, E., Orr, M. G., Sackoff, J., \& Santelli, J. S. (2010). Pregnancy risk among black, white, and Hispanic teen girls in New York City Public Schools. Journal of Urban Health, 87, 426-439.

Warner, M. B., Morey, L. C., Finch, J. F., Skodol, A. E., Shea, M. T., Gunderson, J. G., Sanislow, C. A., McGlashan, T. H., \& Grilo, C. M. 
(2004). The longitudinal relationship of personality traits and disorders. Journal of Abnormal Psychology, 113, 217-227.

Widiger, T. A., \& Costa, P. T. (1994). Personality and personality disorders. Journal of Abnormal Psychology, 103, 78-91.

Widiger, T. A., Trull, T. J., Clarkin, J. F., Sanderson, C., \& Costa, P. T. (2002). A description of the personality disorders with the fivefactor model of personality. In T. A. Widiger \& T. A. Costa (Eds.), Personality disorders and the five-factor model of personality. Washington, DC: American Psychological Association.

Wiggins, N., Blackburn, M., \& Hackman, J. R. (1969). The prediction of first-year success in psychology: peer ratings. Journal of Educational Research, 63, 81-85.

Wilson, E. O. (2000). Sociobiology: the new synthesis: 25th anniversary edition. Cambridge: Harvard University Press.
Wilson, E. O. (2004). On human nature. Cambridge: Harvard University Press.

Wilson, G. (2007). Race, ethnicity, and inequality in the US labor market: critical issues in the new millennium: introduction. The Annals of the American Academy of Political and Social Science, 609, 6-215.

Xiao, J. J. (2008). Handbook of consumer finance research. New York: Springer.

Yoder, J. B., Clancey, E., Des Roches, S., Eastman, J. M., Gentry, L., et al. (2010). Ecological opportunity and the origin of adaptive radiations. Journal of Evolutionary Biology, 23, 1581-1596.

Zytkoskee, A., Strickland, B. R., \& Watson, J. (1971). Delay of gratification and internal versus external control among adolescents of low socioeconomic status. Developmental Psychology, 4, 93-98. 